\title{
Cluster headache in adults
}

\section{SUMMARY}

Cluster headache is characterised by attacks of very severe, unilateral headache lasting 15-180 minutes, up to eight times per day. The attacks are associated with cranial autonomic symptoms on the same side and a sense of agitation or restlessness.

First-line acute abortive treatments include intranasal or subcutaneous sumatriptan or high-flow oxygen. Neuromodulation may benefit some patients.

First-line preventive therapy is high-dose verapamil. Close monitoring is required for the adverse effect of arrhythmia.

There are several emerging therapies that have either proven efficacy, or possible benefit for cluster headache. They include drugs aimed at the calcitonin gene-related peptide.

\section{Introduction}

Cluster headache is a type of trigeminal autonomic cephalalgia. It is known colloquially as the 'suicide headache' because it is among the worst pains that can be experienced and many patients contemplate suicide during the attacks. ${ }^{1,2}$ Compounding the morbidity of the disease, there can be a significant delay in diagnosis of up to eight years, and therefore a delay in optimal treatment. ${ }^{3}$

\section{Epidemiology}

The pooled lifetime prevalence of cluster headache is $0.12 \%$. There is an overall male predominance of 4.3:1, which is higher in chronic cluster headache (15:1) than in episodic cluster headache (3.8:1). ${ }^{4}$ There is a significant genetic component with first-degree relatives having an 18 times higher risk of the disease. ${ }^{5}$ Attacks are triggered by the interplay of endogenous and exogenous factors such as alcohol and seasonal and diurnal variation. Smoking is a well-known risk factor in chronic cluster headache. ${ }^{6}$

\section{Diagnosis}

Cluster headache accounts for $20 \%$ of headaches which always occur on the same side of the head (side-locked headache). ${ }^{7}$ When evaluating a patient, secondary causes of headache should first be considered and excluded. An anterior location of pain, sense of internal restlessness or agitation, and ipsilateral autonomic features (conjunctival injection, lacrimation, rhinorrhoea, eyelid oedema, sweating, miosis or ptosis) are highly suggestive of one of the trigeminal autonomic cephalalgias. The duration of pain and response to treatment helps differentiate these conditions (see Fig.). ${ }^{7}$
Cluster headaches are characterised by severe pain occurring over the orbit, supraorbital or temporal region lasting 15-180 minutes. They are associated with ipsilateral cranial autonomic features and a sense of internal restlessness or agitation (see Box). ${ }^{8}$ During cluster periods, cluster headache attacks occur up to eight times per day, typically at night. ${ }^{8}$ In episodic cluster headache the cluster periods last between seven days and one year and are separated by painfree remission periods of three months or more. The $10-15 \%$ of patients who do not experience remission, or have a remission lasting less than three months, have chronic cluster headache. ${ }^{5,8}$ All patients presenting with cluster headache require MRI of the brain, including the pituitary region to exclude a secondary cause mimicking cluster headache ('symptomatic cluster headache'). These include vascular causes, inflammatory pathology or a neoplasm. ${ }^{9}$

Paroxysmal hemicrania is another type of the trigeminal autonomic cephalalgia. The headache can be of similar duration to cluster headache, but there are more attacks (5-40/day) and no nocturnal emphasis. It responds to a trial of indometacin $(25 \mathrm{mg}$ three times a day then increasing, if there is no or only a partial effect, at three-day intervals to $50 \mathrm{mg}$, then 75 mg three times a day with gastric ulcer prophylaxis). ${ }^{10}$ The gastric ulcer prophylaxis is stopped when the indometacin is stopped.

\section{Pathophysiology}

The pathophysiology of cluster headache is not completely understood. With advances in clinical and neuroimaging studies, the vascular theory of cluster headache is now considered incomplete." There are vascular changes, but they are a consequence

\section{Jason C Ray \\ Neurologist, 1,2 \\ Headache fellow ${ }^{3}$ \\ Richard J Stark \\ Neurologist ${ }^{1}$ \\ Adjunct clinical associate professor $^{3}$}

\section{Elspeth J Hutton (iD}

Deputy director and

Neurologist ${ }^{1}$

Head, Headache Service

Head, Peripheral

Neuropathy, Pain and

Headache Group ${ }^{3}$

'Department of Neurology, Alfred Hospital

2 Department of Neurology, Austin Health

3 Department of

Neuroscience, Monash University

Melbourne

\section{Keywords}

cluster headache, calcitonin gene-related peptide, trigeminal autonomic cephalalgias, triptans

Aust Prescr 2022;45:15-20 https://doi.org/10.18773/ austprescr.2022.004 


\section{Fig. Evaluation of a side-locked headache ${ }^{7}$}

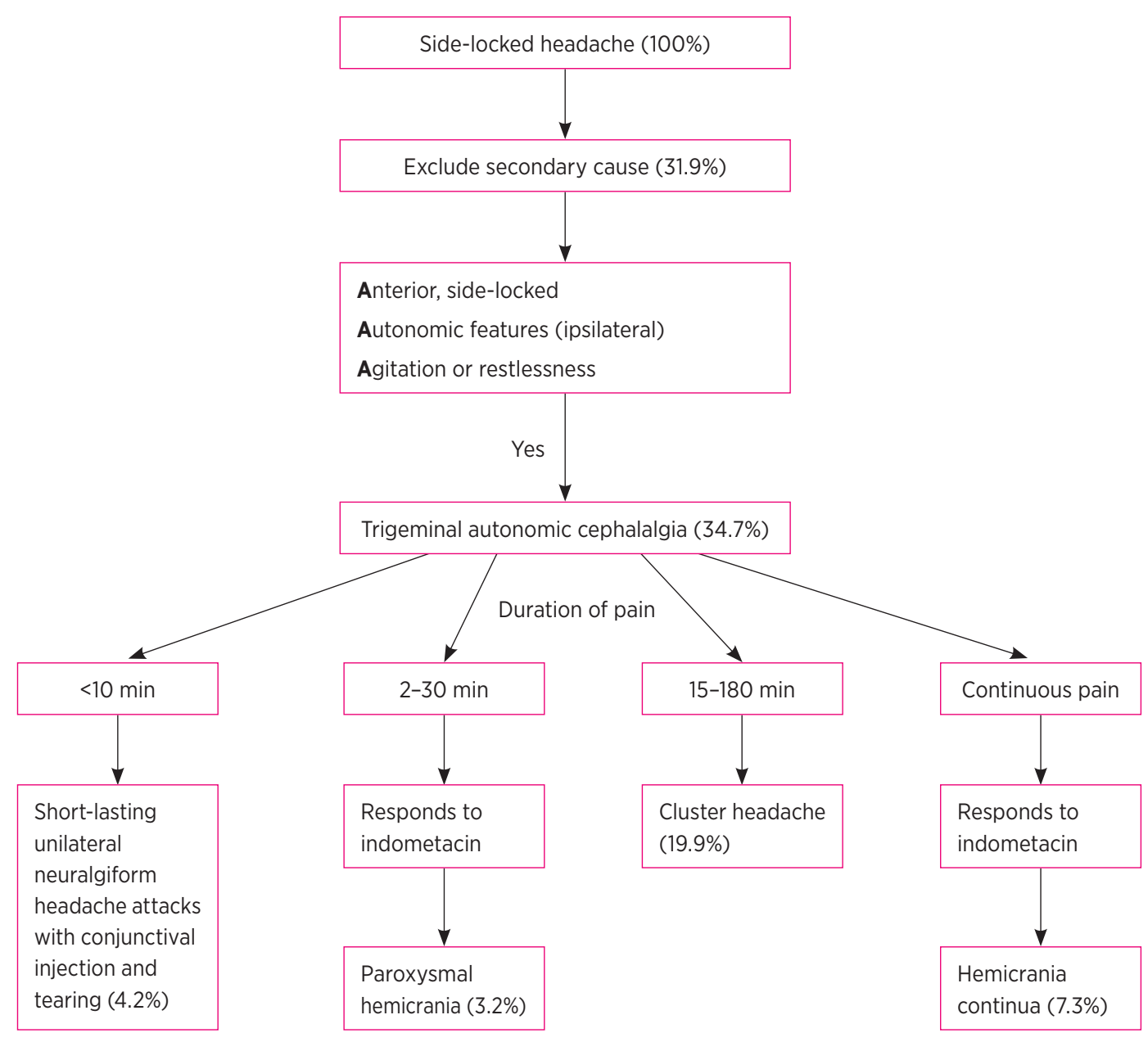

\section{Box Diagnostic criteria for cluster headache ${ }^{8}$}

A At least five attacks fulfilling criteria B-D

B Severe or very severe unilateral orbital, supraorbital and/or temporal pain lasting 15-180 minutes (when untreated)

C Either or both of the following:

1. At least one of the following symptoms or signs, ipsilateral to the headache:

- conjunctival injection or lacrimation

- nasal congestion or rhinorrhoea

- eyelid oedema

- forehead and facial sweating

- miosis or ptosis

2. A sense of restlessness or agitation

D Occurring with a frequency between one every other day and eight per day

E Not better accounted for by another diagnosis of neurological processes. While the precise mechanisms are still debated, recognition of three key structures involved in the pathophysiology aids in the understanding of the clinical features of the disease. These are the:

- trigeminovascular system

- parasympathetic system

- hypothalamus. $^{12}$

The trigeminocervical complex connects the peripheral trigeminal neurons to the central nervous system. Activation of the trigeminal system results in release of several neuropeptides including calcitonin gene-related peptide, a potent vasodilator, through activation of transient receptor potential cation subfamily $V_{1}\left(T_{R P V}\right)^{5,13}$ As pain is perceived unilaterally in the ophthalmic division of the trigeminal nerve, the activation is theorised to be unilateral. However, this theory is unproven and the inefficacy of neurolysis of the trigeminal nerve serves as evidence that the origin of the perception of pain is incompletely understood. ${ }^{5,1}$ 
The trigeminal nerve connects through the superior salivatory nucleus to the parasympathetic fibres of the facial nerve, where they pass through the sphenopalatine ganglion. Activation of the parasympathetic system by the trigeminal nerve (termed the trigeminal autonomic reflex) is also responsible for the release of various neuropeptides including pituitary adenylate cyclase-activating polypeptide (PACAP) ${ }^{5}$ and ipsilateral cranial autonomic symptoms.

Functional imaging shows that the hypothalamus is involved in the circadian and circannual rhythmicity of cluster headache. ${ }^{14}$ The suprachiasmatic nucleus plays a critical role in circadian rhythm, and the nocturnal peak of melatonin is blunted in patients with cluster headache, however the significance of this is unclear. ${ }^{5}$

\section{Approach to management}

Management of cluster headache may be divided into acute abortive and preventive therapies, possibly with bridging therapy between them. The drugs used for the acute and preventive treatment of cluster headache are off label, but supported by clinical evidence. The majority of patients require preventive therapy, however patients with episodic cluster headache with seasonal bouts may only require abortive therapy, which provides symptomatic benefit but does not alter the cluster duration, or shortterm prevention. Bridging therapies are frequently used at the start of a cluster to control attacks while up-titrating preventive therapy. During a bout of attacks, avoiding triggers such as alcohol, nitratecontaining foods and strong odours can be beneficial. ${ }^{15}$

\section{Acute treatment}

First-line, evidence-based, abortive treatments for cluster headache include triptans and high-flow 100\% oxygen through a well-fitting mask (Table 1).,515-21 While several formulations of triptans have been studied in cluster headache, subcutaneous or intranasal preparations are recommended for their rapid onset of action. Triptans can be repeated after two hours. Although patients find both are helpful, there has been no head-to-head trial comparison of oxygen and subcutaneous sumatriptan. ${ }^{22}$ Oxygen, which is delivered via a non-rebreather mask and oxygen cylinder at 7-12 L/minute for 15 minutes, may be ordered from medical gas supply companies in Australia with a prescription.

The choice of acute therapy depends on patient factors and cost. Oxygen is contraindicated in active smokers and patients with type 2 respiratory failure. Triptans are contraindicated in patients with ischaemic heart disease.

Other abortive treatments that have some supporting evidence in cluster headache include noninvasive stimulation of the vagal nerve. ${ }^{23}$ Trials are investigating other forms of neuromodulation.

\section{Table 1 Acute abortive therapies for cluster headache ${ }^{5,15-21}$}

\begin{tabular}{|c|c|c|c|}
\hline Therapy & $\begin{array}{l}\text { Dose } \\
\text { (maximum } 24 \text { h) }\end{array}$ & $\begin{array}{l}\text { Efficacy } \\
\text { Proportion with response (placebo response) }\end{array}$ & Possible mechanism of action \\
\hline $\begin{array}{l}\text { Sumatriptan } \\
\text { (subcutaneous) }\end{array}$ & $\begin{array}{l}6 \mathrm{mg} \\
(12 \mathrm{mg})\end{array}$ & $\begin{array}{l}\text { Mild or no pain at } 15 \min : 75 \%(32 \%) \\
\text { Pain-free at } 15 \min : 48 \%(17 \%)\end{array}$ & \multirow{4}{*}{$\begin{array}{l}5-\mathrm{HT}_{\mathrm{B} / \mathrm{D} / \mathrm{F}} \text { receptors - inhibit } \\
\text { calcitonin gene-related peptide } \\
\text { release and nociceptive signalling } \\
\text { in trigeminocervical complex, } \\
\text { and cause vasoconstriction of } \\
\text { cerebral vessels which is possibly } \\
\text { contributory }\end{array}$} \\
\hline $\begin{array}{l}\text { Sumatriptan } \\
\text { (intranasal) }\end{array}$ & $\begin{array}{l}20 \mathrm{mg} \\
(40 \mathrm{mg})\end{array}$ & $\begin{array}{l}\text { Mild or no pain at } 30 \text { min: } 57 \%(26 \%) \\
\text { Pain-free at } 30 \text { min: } 47 \%(18 \%)\end{array}$ & \\
\hline $\begin{array}{l}\text { Zolmitriptan } \\
\text { (intranasal)* }\end{array}$ & $\begin{array}{l}5 \mathrm{mg} \\
(20 \mathrm{mg})\end{array}$ & $\begin{array}{l}\text { Mild or no pain at } 15 \mathrm{~min}: 15 \% \text { ( } 7 \%) \text {, at } 30 \mathrm{~min}: 45 \% \text { (30\%) } \\
\text { Pain-free at } 15 \mathrm{~min}: 8 \%(3 \%) \text {, at } 30 \mathrm{~min}: 32 \%(18 \%)\end{array}$ & \\
\hline $\begin{array}{l}\text { Zolmitriptan } \\
\text { (intranasal)* }\end{array}$ & $\begin{array}{l}10 \mathrm{mg} \\
(20 \mathrm{mg})\end{array}$ & $\begin{array}{l}\text { Mild or no pain at } 15 \mathrm{~min}: 28 \% \text { (7\%), at } 30 \mathrm{~min}: 62 \% \text { (30\%) } \\
\text { Pain-free at } 15 \mathrm{~min}: 12 \% \text { (3\%), at } 30 \mathrm{~min}: 48 \%(18 \%)\end{array}$ & \\
\hline High-flow oxygen & $7-12 \mathrm{~L} / \mathrm{min}$ for $15 \mathrm{~min}$ & $\begin{array}{l}\text { Reduction in pain at } 15 \mathrm{~min}: 78 \% \text { (20\%) } \\
\text { Pain-free at } 15 \mathrm{~min}: 78 \%(20 \%)\end{array}$ & $\begin{array}{l}\text { Vasoconstriction, blocks trigeminal } \\
\text { autonomic reflex, inhibits protein } \\
\text { release and activity in the superior } \\
\text { salivatory nucleus }\end{array}$ \\
\hline $\begin{array}{l}\text { Non-invasive vagal } \\
\text { nerve stimulation } \\
\text { (episodic cluster } \\
\text { headache only) }\end{array}$ & $\begin{array}{l}3 \text { stimulations for } \\
2 \mathrm{~min}\end{array}$ & Mild or no pain at 15 min: $39 \%$ (12\%) & $\begin{array}{l}\text { Blocks trigeminal autonomic reflex, } \\
\text { inhibits nociceptive signalling in } \\
\text { trigeminocervical complex }\end{array}$ \\
\hline
\end{tabular}

* Intranasal zolmitriptan is currently not available in Australia. 


\section{Bridging therapies}

Despite a lack of supportive randomised data, prednisolone is commonly used as a bridging preventive strategy to allow the up-titration of safer long-term preventive therapies. A variety of prednisolone regimens have been successful in uncontrolled studies, however prolonged use should be minimised because of its adverse effects. Starting at $1 \mathrm{mg} / \mathrm{kg}$ (maximum dose $75 \mathrm{mg}$ daily) with gastric ulcer prophylaxis, and down-titrating over two weeks, is one reasonable strategy. . $^{15,16}$

An alternative strategy is a greater occipital nerve block with an injection of local anaesthetic and depotmethylprednisolone. This combination can reduce attacks for on average four weeks and avoids the adverse effects of a course of oral steroids. ${ }^{24}$

\section{Preventive therapy}

Preventive therapy may be indicated long term in patients with chronic cluster headache, or seasonally, in patients with episodic cluster headache, depending on their history. Immediate-release or controlledrelease verapamil is first line, and its use is supported by a randomised controlled trial, in which $80 \%$ of patients had a halving of attack frequency and $26 \%$ were attack free. ${ }^{25}$ Its efficacy is dose-dependent and the doses required for disease control can be in excess of the usual dose. Specialists can sometimes use up to $960 \mathrm{mg}$ per day in divided doses (Table 2). 5,15,16 Patients therefore require ECG monitoring before starting verapamil, during titration, and even after reaching a stable dose. One in five patients will develop an arrhythmia and delayed-onset arrhythmias have been reported. ${ }^{26,27}$ Arrhythmias include first-degree heart block, second-degree heart block, junctional rhythms, right bundle branch block and bradycardia. ${ }^{26}$ There is a need to check for drug interactions. Once a bout of cluster headache has finished, the patient can be weaned cautiously off verapamil, by $80 \mathrm{mg}$ every one to two weeks.

Lithium is considered second-line for the prevention of cluster headache. There are limited controlled

Table 2 Preventive therapy for cluster headache $e^{5,15,16}$

\begin{tabular}{|c|c|c|c|c|}
\hline Drug & Dosing & Monitoring & Possible adverse effects & $\begin{array}{l}\text { Possible mechanism of } \\
\text { action }\end{array}$ \\
\hline $\begin{array}{l}\text { Verapamil } \\
\text { (immediate-release } \\
\text { formulation*) } \\
\text { (Grade 1B) }\end{array}$ & $\begin{array}{l}\text { Start: } 80 \mathrm{mg} \text { three times a } \\
\text { day for at least } 2 \text { weeks } \\
\text { Titrate: increase by } 80 \mathrm{mg} \\
\text { every } 2 \text { weeks } \\
\text { Range: } 240-960 \mathrm{mg}\end{array}$ & $\begin{array}{l}\text { ECG: before starting and at } \\
\text { every dose change } \\
\text { Repeat at stable dose after } \\
10 \text { days, every } 1-2 \text { months } \\
\text { then every } 6 \text { months }\end{array}$ & $\begin{array}{l}\text { Constipation, peripheral } \\
\text { oedema, bradycardia, } \\
\text { conduction abnormalities. } \\
\text { Cytochrome P450 3A4 } \\
\text { inhibitor. There is a potential } \\
\text { for drug interactions }\end{array}$ & $\begin{array}{l}\text { Voltage-gated calcium } \\
\text { channels: decreases } \\
\text { calcitonin gene-related } \\
\text { peptide release, alters } \\
\text { circadian rhythm }\end{array}$ \\
\hline $\begin{array}{l}\text { Lithium } \\
\text { (Grade 1B) }\end{array}$ & $\begin{array}{l}\text { Start: } 300 \mathrm{mg} \text { daily for at } \\
\text { least } 1 \text { week } \\
\text { Titrate: increase by } 300 \mathrm{mg} \\
\text { every week } \\
\text { Range: } 300-1200 \mathrm{mg}\end{array}$ & $\begin{array}{l}\text { Monitor thyroid, kidney } \\
\text { function, calcium, magnesium } \\
\text { Monitor lithium concentration } \\
\text { (initial aim } 0.6-0.8 \mathrm{mmol} / \mathrm{L} \text { ) }\end{array}$ & $\begin{array}{l}\text { Include tremor, dizziness, } \\
\text { dry mouth, weight gain, } \\
\text { fatigue, anorexia, ataxia, } \\
\text { gastrointestinal upset }\end{array}$ & $\begin{array}{l}\text { Alters glutamate, } \\
\text { dopamine, gamma } \\
\text { aminobutyric acid, } \\
\text { circadian rhythm }\end{array}$ \\
\hline $\begin{array}{l}\text { Galcanezumab } \\
\text { (episodic) }\end{array}$ & $\begin{array}{l}\text { Start: } 240 \text { mg subcutaneous } \\
\frac{\text { Continue: } 120 \text { mg every }}{4 \text { weeks }}\end{array}$ & Not required & $\begin{array}{l}\text { Constipation, local } \\
\text { injection site reaction, } \\
\text { nasopharyngitis }\end{array}$ & $\begin{array}{l}\text { Inhibition of calcitonin } \\
\text { gene-related peptide }\end{array}$ \\
\hline $\begin{array}{l}\text { Topiramate } \\
\text { (Grade 1B) }\end{array}$ & $\begin{array}{l}\text { Start: } 25 \mathrm{mg} \text { daily for } \geq 1 \text { week } \\
\text { Titrate: increase by } \\
\text { 25-50 mg/week } \\
\text { Range: } 100-200 \mathrm{mg}\end{array}$ & Monitor kidney function & $\begin{array}{l}\text { Cognitive slowing, } \\
\text { paraesthesia, kidney } \\
\text { stones, gastrointestinal } \\
\text { upset }\end{array}$ & $\begin{array}{l}\text { Inhibits trigeminal } \\
\text { nociception, enhances } \\
\text { gamma aminobutyric acid }\end{array}$ \\
\hline $\begin{array}{l}\text { Melatonin } \\
\text { (Grade 2C) }\end{array}$ & $\begin{array}{l}\text { Start: } 4 \text { mg daily for } \geq 1 \text { week } \\
\text { Titrate: increase by } 4 \mathrm{mg} \\
\text { every week } \\
\text { Range: typically } 8-10 \mathrm{mg}, \\
\text { compounded }\end{array}$ & Monitor sedation & $\begin{array}{l}\text { Drowsiness, } \\
\text { gastrointestinal upset }\end{array}$ & $\begin{array}{l}\text { Alters circadian rhythm, } \\
\text { enhances gamma } \\
\text { aminobutyric acid }\end{array}$ \\
\hline
\end{tabular}

* Controlled-release formulation may also be used with twice-daily dosing Grade 1 strong recommendation Grade 2 weak recommendation Grade A high-level evidence Grade B moderate-level evidence 
data on its use, however in one trial it had similar efficacy to verapamil, but more adverse effects ( $29 \%$ vs $12 \%$ ). ${ }^{28}$ The use of lithium is limited by its long-term adverse effects, toxicity and the need for strict monitoring.

Topiramate showed efficacy in a single open-label trial, but while it is a reasonable third-line option, cognitive adverse effects may limit its use. ${ }^{29}$ There is also weaker evidence for pizotifen and gabapentin, and conflicting evidence for melatonin and valproate. They are generally used as adjuvant therapies to other preventive drugs. $5,15,30$

\section{Neuromodulation}

Several invasive and non-invasive neuromodulatory techniques have been investigated in cluster headache. Electrical stimulation of the sphenopalatine ganglion, occipital nerve and vagal nerve have all been effective at reducing attack frequency. However, these procedures are reserved for drug-refractory cluster headache due to the need for surgery, their cost and the risk of complications. ${ }^{5}$ Access to invasive neuromodulatory techniques in Australia is limited.

Neuromodulation can be highly effective in select groups. In a randomised controlled trial of sphenopalatine ganglion neurostimulation (involving implantation of a device not available in Australia) for refractory cluster headache, $67 \%$ of patients achieved pain relief. ${ }^{31}$ Other trials studied radiofrequency ablation of the sphenopalatine ganglion. In the largest case series of 66 patients there was pain relief in $60 \%$ of those with episodic cluster headache and in $30 \%$ of those with chronic cluster headache. ${ }^{31,32}$

A phase III trial of occipital nerve stimulation has been completed. It compared low- (30\%) and high-intensity (100\%) stimulation for refractory chronic cluster headache. Overall, the median weekly mean attack frequency reduced to 7.4. The reduction was greater in the high-stimulation group. However, the difference between the groups was -2.42 (95\% confidence interval -5.17 to 3.33 ). Serious adverse events, such as pain, were reported in $26 \%$ of the high-stimulation and $12 \%$ of the lowstimulation groups. ${ }^{33}$

Non-invasive stimulation of the vagus nerve has been studied for acute treatment of cluster headache in two randomised, sham-controlled trials. There was a significant response in episodic cluster headache, but not chronic cluster headache. ${ }^{34,35}$ In one trial of non-invasive stimulation of the vagus nerve for prevention, the number of weekly attacks reduced by 5.9 compared to 2.1 with sham treatment. ${ }^{36}$

\section{Emerging therapies}

Galcanezumab is a monoclonal antibody against calcitonin gene-related peptide. In episodic cluster headache galcanezumab reduced weekly attacks by $71 \%$. Fremanezumab, another calcitonin generelated peptide monoclonal antibody, was not effective in episodic cluster headache. Neither drug was effective for chronic cluster headache. ${ }^{37}$ This may have been due to poor trial design and differing neurobiology between episodic cluster headache and chronic cluster headache. ${ }^{37,38}$ Trials of eptinezumab, an intravenous calcitonin gene-related peptide monoclonal antibody, in episodic cluster headache are ongoing (NCT04688775).

Three prospective studies of onabotulinum toxin A using a variety of protocols have provided low-quality evidence that it may reduce attack frequency in cluster headache by up to $50 \% .{ }^{39}$ A phase I-II trial of onabotulinum toxin A injected towards the otic ganglia found it to be safe in chronic cluster headache, but there was no significant reduction in attack frequency. ${ }^{40}$ A phase III trial is studying injections towards the sphenopalatine ganglion (NCT03944876)

\section{Referral}

Early specialist referral and co-management are recommended if there is any diagnostic uncertainty about the condition. A suboptimal response to management or a need for second- or third-line treatments are also indications for referral.

\section{Conclusion}

A cluster headache is one of the most excruciating pains imaginable. Recognising the condition and empowering patients with a plan for managing acute attacks and bridging therapies while titrating preventive therapy is key to limiting the morbidity of the disease. $<$

Conflicts of interest: Jason Ray has received compensation from the Pharmaceutical Society of Australia, sponsored by Viatris for educational material.

Richard Stark has served on advisory boards for Novartis, Teva, Eli Lilly, Allergan, Lundbeck and has received payment for educational presentations from Allergan, Teva, Eli Lilly and Novartis.

Elspeth Hutton has served on advisory boards for Sanofi-Genzyme, Novartis, Teva, Eli Lilly, Allergan, Lundbeck, been involved in clinical trials sponsored by Novartis, Teva, Xalud, Daewong and Novotech, and has received payment for educational presentations from Allergan, Teva, Eli Lilly and Novartis. 


\section{REFERENCES}

1. Ji Lee M, Cho SJ, Wook Park J, Kyung Chu M, Moon HS, Chung PW, et al. Increased suicidality in patients with cluster headache. Cephalalgia 2019;39:1249-56. https://doi.org/10.1177/0333102419845660

2. Fletcher J. Why cluster headaches are called 'suicide headaches'. J Neurol Stroke 2015;3:00092. https://doi.org/10.15406/jnsk.2015.03.00092

3. Buture A, Ahmed F, Dikomitis L, Boland JW. Systematic literature review on the delays in the diagnosis and misdiagnosis of cluster headache. Neurol Sci 2019;40:25-39. https://doi.org/10.1007/s10072-018-3598-5

4. Fischera M, Marziniak M, Gralow I, Evers S. The incidence and prevalence of cluster headache: a meta-analysis of population-based studies. Cephalalgia 2008;28:614-8. https://doi.org/10.1111/j.1468-2982.2008.01592.x

5. Hoffmann J, May A. Diagnosis, pathophysiology, and management of cluster headache. Lancet Neurol 2018;17:75-83. https://doi.org/10.1016/ S1474-4422(17)30405-2

6. Donnet A, Lanteri-Minet M, Guegan-Massardier E, Mick G, Fabre N Géraud G, et al.; Société Française d'Etude des Migraines et Céphalées (SFEMC). Chronic cluster headache: a French clinical descriptive study. J Neurol Neurosurg Psychiatry 2007;78:1354-8. https://doi.org/10.1136/ jnnp.2006.112037

7. Prakash S, Rathore C. Side-locked headaches: an algorithm-based approach. J Headache Pain 2016;17:95. https://doi.org/10.1186/s10194-016-0687-9

8. The international classification of headache disorders, 3rd edition. Cephalagia 2018;38:1-211. https://ichd-3.org [cited 2022 Jan 4]

9. De Pue A, Lutin B, Paemeleire K. Chronic cluster headache and the pituitary gland. J Headache Pain 2016;17:23. https://doi.org/10.1186/s10194-016-0614-0

10. Matharu MS, Cohen AS. Paroxysmal hemicrania: clinical features and diagnosis. UpToDate 2020 Jan 03. www.uptodate.com/contents/paroxysmalhemicrania-clinical-features-and-diagnosis [cited 2022 Jan 4]

11. May A, Schwedt TJ, Magis D, Pozo-Rosich P, Evers S, Wang SJ. Cluster headache. Nat Rev Dis Primers 2018;4:18006. https://doi.org/10.1038/ nrdp.2018.6

12. Ljubisavljevic S, Zidverc Trajkovic J. Cluster headache: pathophysiology, diagnosis and treatment. J Neurol 2019;266:1059-66. https://doi.org/10.1007/ s00415-018-9007-4

13. Meng J, Ovsepian SV, Wang J, Pickering M, Sasse A, Aoki KR, et al. Activation of TRPV1 mediates calcitonin gene-related peptide release, which excites trigeminal sensory neurons and is attenuated by a retargeted botulinum toxin with anti-nociceptive potential. J Neurosci 2009;29:4981-92. https://doi.org/ 10.1523/JNEUROSCI.5490-08.2009

14. Yang FC, Chou KH, Kuo CY, Lin YY, Lin CP, Wang SJ. The pathophysiology of episodic cluster headache: Insights from recent neuroimaging research. Cephalalgia 2018;38:970-83. https://doi.org/10.1177/0333102417716932

15. Wei DY, Khalil M, Goadsby PJ. Managing cluster headache. Pract Neurol 2019;19:521-8. https://doi.org/10.1136/practneurol-2018-002124

16. May A, Leone M, Afra J, Linde M, Sándor PS, Evers S, et al.; EFNS Task Force. EFNS guidelines on the treatment of cluster headache and other trigeminalautonomic cephalalgias. Eur J Neurol 2006;13:1066-77. https://doi.org/10.1111/ j.1468-1331.2006.01566.x

17. Mecklenburg J, Sanchez Del Rio M, Reuter U. Cluster headache therapies: pharmacology and mode of action. Expert Rev Clin Pharmacol 2020;13:641-54. https://doi.org/10.1080/17512433.2020.177436

18. de Coo IF, Marin JC, Silberstein SD, Friedman DI, Gaul C, McClure CK, et al Differential efficacy of non-invasive vagus nerve stimulation for the acute treatment of episodic and chronic cluster headache: A meta-analysis. Cephalalgia 2019;39:967-77. https://doi.org/10.1177/0333102419856607

19. Cohen AS, Burns B, Goadsby PJ. High-flow oxygen for treatment of cluster headache: a randomized trial. JAMA 2009;302:2451-7. https://doi.org/10.1001/ jama.2009.1855

20. Law S, Derry S, Moore RA. Triptans for acute cluster headache. Cochrane Database Syst Rev 2013:CD008042. https://doi.org/10.1002/ 14651858.cd008042.pub3

21. van Vliet JA, Bahra A, Martin V, Ramadan N, Aurora SK, Mathew NT, et al. Intranasal sumatriptan in cluster headache: randomized placebo-controlled double-blind study. Neurology 2003;60:630-3. https://doi.org/10.1212/ 01.WNL.0000046589.45855.30

22. Pearson SM, Burish MJ, Shapiro RE, Yan Y, Schor LI. Effectiveness of oxygen and other acute treatments for cluster headache: results from the cluster headache questionnaire, an international survey. Headache 2019;59:235-49. https://doi.org/10.1111/head.13473
23. Mwamburi M, Liebler EJ, Tenaglia AT. Review of non-invasive vagus nerve stimulation (gammaCore): efficacy, safety, potential impact on comorbidities, and economic burden for episodic and chronic cluster headache. Am J Manag Care 2017;23(Suppl):S317-25.

24. Ambrosini A, Vandenheede M, Rossi P, Aloj F, Sauli E, Pierelli F, et al. Suboccipital injection with a mixture of rapid-and long-acting steroids in cluster headache: a double-blind placebo-controlled study. Pain 2005;118:92-6. https://doi.org/10.1016/j.pain.2005.07.015

25. Petersen AS, Barloese MC, Snoer A, Soerensen AM, Jensen RH. Verapamil and cluster headache: still a mystery. a narrative review of efficacy, mechanisms and perspectives. Headache 2019;59:1198-211. https://doi.org/10.1111/ head. 13603

26. Cohen AS, Matharu MS, Goadsby PJ. Electrocardiographic abnormalities in patients with cluster headache on verapamil therapy. Neurology 2007;69:668-75 https://doi.org/10.1212/01.wnl.0000267319.18123.d3

27. Lanteri-Minet M, Silhol F, Piano V, Donnet A. Cardiac safety in cluster headache patients using the very high dose of verapamil ( $\geq 720 \mathrm{mg} / \mathrm{day}$ ). J Headache Pain 2011;12:173-6. https://doi.org/10.1007/s10194-010-0289-x

28. Bussone G, Leone M, Peccarisi C, Micieli G, Granella F, Magri M, et al. Double blind comparison of lithium and verapamil in cluster headache prophylaxis. Headache 1990;30:411-7. https://doi.org/10.1111/j.1526-4610.1990.hed3007411.x

29. Leone M, Dodick D, Rigamonti A, D’Amico D, Grazzi L, Mea E, et al. Topiramate in cluster headache prophylaxis: an open trial. Cephalalgia 2003;23:1001-2. https://doi.org/10.1046/j.1468-2982.2003.00665.x

30. Leone M, Giustiniani A, Cecchini AP. Cluster headache: present and future therapy. Neurol Sci 2017;38 Suppl 1:45-50. https://doi.org/10.1007/ s10072-017-2924-7

31. Ho KW, Przkora R, Kumar S. Sphenopalatine ganglion: block, radiofrequency ablation and neurostimulation - a systematic review. J Headache Pain 2017;18:118. https://doi.org/10.1186/s10194-017-0826-y

32. Sanders M, Zuurmond WW. Efficacy of sphenopalatine ganglion blockade in 66 patients suffering from cluster headache: a 12- to 70-month followup evaluation. J Neurosurg 1997;87:876-80. https://doi.org/10.3171/ jns.1997.87.6.0876

33. Wilbrink LA, de Coo IF, Doesborg PG, Mulleners WM, Teernstra OP, Bartels EC et al.; ICON study group. Safety and efficacy of occipital nerve stimulation for attack prevention in medically intractable chronic cluster headache (ICON): a randomised, double-blind, multicentre, phase 3 , electrical dose-controlled trial. Lancet Neurol 2021;20:515-25. https://doi.org/10.1016/S1474-4422(21)00101-0

34. Goadsby PJ, de Coo IF, Silver N, Tyagi A, Ahmed F, Gaul C, et al.; ACT2 Study Group. Non-invasive vagus nerve stimulation for the acute treatment of episodic and chronic cluster headache: A randomized, double-blind, shamcontrolled ACT2 study. Cephalalgia 2018;38:959-69. https://doi.org/10.1177/ 0333102417744362

35. Silberstein SD, Mechtler LL, Kudrow DB, Calhoun AH, McClure C, Saper JR, et al.; ACT1 Study Group. Non-invasive vagus nerve stimulation for the acute treatment of cluster headache: findings from the randomized, double-blind, sham-controlled ACT1 study. Headache 2016;56:1317-32. https://doi.org/ 10.1111/head.12896

36. Gaul C, Diener HC, Silver N, Magis D, Reuter U, Andersson A, et al.; PREVA Study Group. Non-invasive vagus nerve stimulation for PREVention and Acute treatment of chronic cluster headache (PREVA): a randomised controlled study. Cephalalgia 2016;36:534-46. https://doi.org/10.1177/0333102415607070

37. Ray JC, Kapoor M, Stark RJ, Wang SJ, Bendtsen L, Matharu M, et al. Calcitonin gene related peptide in migraine: current therapeutics, future implications and potential off-target effects. J Neurol Neurosurg Psychiatry 2021;92:1325-34. https://doi.org/10.1136/jnnp-2020-324674

38. Giani L, Proietti Cecchini A, Leone M. Galcanezumab for the prevention of cluster headache. Expert Opin Biol Ther 2020;20:1133-42. https://doi.org/ 10.1080/14712598.2020.1800635

39. Freund B, Kotchetkov IS, Rao A. The Efficacy of botulinum toxin in cluster headache: a systematic review. J Oral Facial Pain Headache 2020;34:129-34. https://doi.org/10.11607/ofph.2444

40. Crespi J, Bratbak D, Dodick DW, Matharu M, Solheim O, Gulati S, et al. Openlabel, multi-dose, pilot safety study of injection of onabotulinumtoxina toward the otic ganglion for the treatment of intractable chronic cluster headache. Headache 2020;60:1632-43. https://doi.org/10.1111/head.13889 